Original Research

\title{
Family Support Required to Increase Compliance of Medical Control of Patients with Cancers
}

\section{Nurul Ramadhani Yaner, Tintin Sukartini, Kristiawati Kristiawati, and M Ruli Maulana}

Faculty of Nursing, Universitas Airlangga, Surabaya, Indonesia

\begin{abstract}
Introduction: Long and burdening therapeutic treatments of patients with cancers require social support in order to encourage patient's medical compliance. Family support helps patients remain positive during their treatments so that they can develop physical and psychological fulfillment. This research identifies the correlation between family's support and the rate of compliance of medical control of patients with cancer.
\end{abstract}

Methods: The design was cross-sectional. The population was 60 patients with cancers who were undertaking treatment and 36 respondents were drawn by using a consecutive sampling technique. The independent variable is family support, while the dependent variable is the rate of compliance of patients with cancers in maintaining their medical control. The data was collected using questionnaires adopted from MMAS-8 (Medication Morisky Adherence Scale) and analyzed by using Chi Square with a significance rate of $\alpha \leq 0.05$.

Results: The results indicated that the correlation between family's support and the rate of medical compliance resulted in $\mathrm{p}=0.006$.

Conclusion: Supportive family support is very important in the successful treatment of cancer patients, because the family is closest to the patient, they live together, and also they have the opportunity to meet the needs of cancer patients.

\section{ARTICLE HISTORY}

Received: Dec 26, 2019

Accepted: Dec 31, 2019

\section{KEYWORDS}

cancer; family support; medical compliance

\section{CONTACT}

M Ruli Maulana

$\triangle$ m.ruli.maulana-

2018@fkp.unair.ac.id

$\fallingdotseq$ Faculty of Nursing, Universitas

Airlangga, Surabaya, Indonesia

Cite this as: Yaner, N.R., Sukartini, T., Kristiawati, K. ,\& Maulana, M.R. (2019). Family Support Required to Increase Compliance of Medical Control of Patients with Cancers. Jurnal Ners, 14(3si), 331-335. doi:http://dx.doi.org/10.20473/jn.v14i3(si).17177

\section{INTRODUCTION}

The prolonged cancer treatment process, fear of death and the absence of family support creates patient frustration and finally leads to stopping treatment (drop-out). According to (Balitbang Kemenkes RI, 2013) said that cancer patients do not often follow to treatment for a variety of reasons such as issues of cost, trying alternative treatments and intolerance to the side effects.

The success of treatment can be determined by the patient's compliance with the recommended treatment. Research on drug adherence to chronic diseases showed that about half of people do not comply with their prescription drugs (Balitbang Kemenkes RI, 2013). Based on a national survey of cancer sufferers, none of the sufferers claimed that they did not always follow the prescribed guidelines correctly and more than half said that they sometimes forgot to take their medication. Several studies have shown that adherence to oral drugs for cancer varies greatly. The level of adherence is usually high at the beginning of treatment or for a short period of time, after which it is rarely done again.

Cancer is still a disease that is a leading cause of death. According to WHO data in 2010, the global death rate from cancer has reached 13 percent (7.4 million) of total deaths annually, and $70 \%$ of cancer deaths occur in low- and middle-income countries. An estimated number of cancer deaths will increase significantly in the coming years, and will reach approximately 13 million deaths per year worldwide in 2030. According to (Brannon, L. Feist, 2997), prevalence of cancer is highest in Indonesian especially Yogyakarta (4.1\%), Central Java (2.1\%), and Bali (2\%), while the East Java was ranked 10 with prevalence rate $(1.6 \%)$. 
Recapitulation of Surabaya City Health Office in 2013 showed that there were 1768 cancer patients enrolled in Surabaya. According to data from the Health Department of Surabaya there are three health centers that provide palliative care for people with cancer in Tambaksari District, Surabaya. The number of patients registered is 60 people, 25 people in Gading, 20 people in Pacar Keling, and 15 people in Rangkah Primary Health Care.

Treatment adherence behavior in cancer patients is essential to increase the cure rate. If it is connected to the Green theory (Kusuma, 2011), behavior is influenced by three factors, predisposing factors, enabling factors and reinforcing factors. The supporting factors include knowledge, attitudes, beliefs and values of the individual against cancer. Enabling factors include the availability of facilities while driving factors include the support of family, friends, health workers, community leaders who lead a cancer patient undergoing treatment compliance. Family support greatly supports the successful treatment of cancer patients, for example by reminding patients to routinely undergo cancer treatment.

Cancer patients given family support in the form of informational support, instrumental support, emotional support and self-esteem support, can increase the quality of life. Family support for cancer patients undergoing palliative therapy will positively influence physical and psychological well-being. Someone receiving family support feels loved, valuable, and able to share the burden, be confident and encourage hope to reduce stress (Green, LW, 2005). The family's role in the cancer client's treatment process is very large. Another study conducted relating to family support also concluded that there was a significant relationship between family support and motivation to treat cancer patients (Green, LW, 2005).

\section{MATERIALS AND METHODS}

\section{Design, population, sample, and variables}

This design was a descriptive correlational research using a cross sectional approach. The population in this study were all patients with cancer in 3 Primary Health Service. Affordable population size in this study were 36 people, in the period from March to July 2016. The sampling technique used in this study was total sampling. Inclusion criteria in this research were 1) patients with cancer, 2) taking cancer palliative therapy, 3) 18 years old and above, and 4) willing to participate into this study, while exclusion criteria were 1) nomadic patient. The independent variable was family's support, while the dependent variable was the rate of compliance of patients with cancers in maintaining their medical control.

\section{Instruments}

A questionnaire for reviewing family support was adopted based on research (Kusuma, 2011). This questionnaire representing questions from 4 sub variables of family support include: emotional support, instrumental support, information support, and self-esteem support. The number of questions was 18 items using a Likert scale with a score of $0-3$, obtained a range of score from 0 to 54 , which are categorized by the formula namely the cut of point $75 \%$ of the total score (54), with results: $\leq 40.5$ : nonsupportive and $\geq 40.5$ : supportive. To measure patient compliance cancer in taking medicine containing 8 items of questions, the author made a modification by adding question number 8 . The question in this questionnaire consists of 7 statements unfavorable and 1 positive statement. Every question answered "yes" is given a score 0 and 1 for questions answered "no". The score in this questionnaire is divided into 3,1 ) score $<6$ is said to be low compliance; 2) score 6-7 is moderate compliance; and 3) score 8 is high compliance using MMAS-8 (Medication Morisky Adherence Scale) that has been translated into Indonesian. The questionnaire has tested the validity and reliability with Cronbach alpha 0.919 .

\section{Research procedures and analysis}

This study has passed the ethical review and obtained an Ethical Approval certificate with No: 203-KEPK issued by Health Research Ethics Committee of Faculty of Nursing, Universitas Airlangga. Research data collection was conducted by measuring the main factors of family support and compliance with cancer patients undergoing control by giving questionnaires regarding family support and compliance with cancer patients undergoing treatment. Statistical analysis used Chi Square. The confidence interval was 95\% with alpha $\alpha=0,05$.

\section{RESULTS}

Characteristic respondents on Table 1 showed that the majority of respondents were female with an average age above 50 years. Based on the educational background, the majority of respondents had high school education. If seen from the background of work, most respondents do not have jobs so that the average income of all respondents can be said to be low.

Based on the table 2 above, it can also be seen that all respondents were married with the majority having a membership of 4 people in one family and the majority of respondents were Muslim. The majority of respondents have low compliance of medical control.

Based on table 3 above, it can be seen that the majority of respondents received support from the family but the value of compliance in medical control is very low. From the chi-square test conducted, a significant relationship between compliance and support was obtained. Decision making can be guided by a comparison of the $\mathrm{p}$-value with a significance level, the reject criterion rejects $H_{0}$ if the p-value $<\alpha$ $(=0.05)$ or by comparing the values of the chi-square count with the chi-square table. The results of the chi- 
Table 1. The demographic characteristics $(n=36)$

\begin{tabular}{|c|c|c|c|c|}
\hline No. & Characteristics & Criteria & $\mathbf{f}$ & $\%$ \\
\hline \multirow[t]{2}{*}{1.} & Gender & Man & 3 & 8.33 \\
\hline & & woman & 33 & 91.67 \\
\hline \multirow[t]{2}{*}{2.} & Age & $36-50$ years & 14 & 38.89 \\
\hline & & $>50$ years & 22 & 61.11 \\
\hline \multirow[t]{5}{*}{3.} & Education & Not completed in primary school & 2 & 5.56 \\
\hline & & Basic School & 5 & 13.89 \\
\hline & & Middle School & 8 & 22.22 \\
\hline & & High School & 20 & 55.56 \\
\hline & & University & 1 & 2.78 \\
\hline \multirow[t]{4}{*}{4.} & Work & Does not work & 25 & 69.44 \\
\hline & & labor & 5 & 13.89 \\
\hline & & entrepreneur & 4 & 11.11 \\
\hline & & Etc. & 2 & 5.56 \\
\hline \multirow[t]{2}{*}{5.} & Income per month & $<650,000$ & 32 & 88.89 \\
\hline & & $>650,000$ & 4 & 11.11 \\
\hline 6. & Marital status & Married & 36 & 100 \\
\hline \multirow[t]{6}{*}{7.} & Number of family members & 2 people & 4 & 11.11 \\
\hline & & 3 people & 5 & 13.89 \\
\hline & & 4 people & 19 & 52.78 \\
\hline & & 5 people & 5 & 13.89 \\
\hline & & 6 people & 2 & 5.56 \\
\hline & & 8 people & 1 & 2.78 \\
\hline \multirow[t]{2}{*}{8.} & Religion & Islam & 35 & 97.22 \\
\hline & & Christian & 1 & 2,78 \\
\hline \multirow[t]{3}{*}{9.} & The type of cancer & Breast cancer & 14 & 38.89 \\
\hline & & Cervical cancer & 19 & 52.78 \\
\hline & & Lung cancer & 3 & 8.33 \\
\hline
\end{tabular}

Table 2. Family support in patients undergoing cancer treatment and Compliance of medical control $(\mathrm{n}=36)$

\begin{tabular}{clcc}
\hline No. & \multicolumn{1}{c}{ Variables } & f & \% \\
\hline 1. & Family Support & 28 & 78 \\
& Supportive & 22 & \\
& Non-supportive & 8 & \\
$2 . \quad$ Compliance of medical control & & 94 \\
& Low & & 6 \\
& Moderate & 34 & 2 \\
\hline
\end{tabular}

Table 3. Cross tabulation Family support and Compliance of medical control

\begin{tabular}{ccccccc}
\hline Family support & \multicolumn{2}{c}{ Compliance of medical control } & & \multicolumn{2}{c}{ Total } \\
& \multicolumn{2}{c}{ Low } & \multicolumn{2}{c}{ Moderate } & & $78 \%$ \\
\hline Supportive & 28 & $78 \%$ & 0 & $0 \%$ & 28 & $22 \%$ \\
\hline Non-supportive & 6 & $17 \%$ & 2 & $5 \%$ & 8 & $100 \%$ \\
\hline Total & 34 & $95 \%$ & 2 & $5 \%$ & 36 & \\
\hline
\end{tabular}

square test between compliance and support show that the p-value is 0.006 , where the p-value is less than $\alpha(=0.05)$, so that the $H_{0}$ decision is rejected and it can be concluded that there is a significant relationship between family support and level compliance with control of cancer patients in undergoing palliative treatment at the puskesmas in Tambakari sub-district Surabaya.

\section{DISCUSSION}

The support obtained from the family in this study was in the form of encouragement to recover in medicine, informing about the benefits and risks if not adhering to taking medication, and reminding them to take medication if the patient forgot. In addition, it also provides encouragement in the form of delivering treatment for sick families. Support was provided for sick family members to meet their food and drink needs, and also bear the costs of medical treatment. If there are problems faced by survivors, the family must provide advice for problem solving. Patients who get good support indicate that the family realizes what the patient really needs.

Support from the family makes the sufferer not feel burdened with his illness. This is due to the attention of his family, so the sufferer does not feel alone. Families can be a significance influencing factor in determining the health beliefs and values of individuals and can also determine the treatment program they can receive. Support provided by family 
members is an important factor in patient compliance with medical treatment that patients undergo.

Also found that family support is the existence, availability, care of people who can rely on, respect and love people (Niven, 2002). Friedman explains that the family has 4 types of support that informational support, self-esteem, instrumental and emotional (Grant, M ; Sun, V ; Fujinami, R ; Sidhu, R; Otis-Green, S ; Juarez, G ; Ferrell, 2013). Informational support is the form of advice, suggestions, advice, guidance, and information sharing. Support ratings of whom provide support, recognition, appreciation and attention. Instrumental support can be direct assistance as material, labor and equipment. While emotional support may be the family as a peaceful place to rest and recovery as well as helping control over emotions

According to researchers, a supportive family is very important in the successful treatment of cancer patients, because the family is the one that is closest to the patient, they live together, the family also has the best opportunity to meet the needs of cancer patients. Moreover, family duties were not only to care for the sick, but should include several aspects, including physical, psychological, social, spiritual, information about cancer. In addition, the most important aspect is the recognition of a family when one of its members suffering from cancer. If family support is provided properly, it will bring a positive effect in the recovery process of cancer patients. Family duties are to not only care for the sick, but must include several aspects, like physical, psychological, social, spiritual, information about cancer and the most important is the recognition of a family when one of its members is suffering from cancer.

In this study the researchers obtained data from 36 respondents and showed that 28 respondents received supportive family support with a percentage of $78 \%$. According to the family support questionnaire that was filled in by patients, it was mostly in question number 1 where the patient said that the family accompanied them during treatment. Question number 2 said that the family showed concern by inviting patients to discuss the problems faced by patients. Question number 6 said the family provided time and facilities if the patient needed medical treatment. In question number 8 patients say the family is willing to pay for care and treatment while the patient is sick. Question number 10 patients say the family helps in carrying out daily activities. Question number 12 the patient reminds the family of controls, taking medication, exercising, resting, and eating healthy food. Question number 17 patients said the family tended the patient to social activities so that the patient did not feel bored with his illness.

Green's theory adherence behavior treatment is influenced by fundamental factors or factors that exist within the individual that influence compliance behavior (predisposing factors), reinforcing factors, and factors that support (enabling factors) (Friedman, MM, Bowden, VR, \& Jones, 2010). While the factors that affect non-compliance are divided into 4 parts, namely the patient's understanding of instruction, the quality of interaction, family, beliefs, attitudes and personality. According to the researcher, family support and adherence to taking medication is closely related to where one of them does not play an important role, what will happen is not adhering to taking the medication. Someone is said to be adherent to treatment if the person is able to complete treatment without ever neglecting any treatment. In this study of 34 respondents (95\%) received treatment adherence levels run low. According to the questionnaire that was filled out by the patient most of the patients answered question No. 1 is patient sometimes forgets to take his medicine, question number 2 patients often miss taking medication in the past two weeks, the question number 4 patients said often leave medication at home when was traveling. Low level of adherence can be influenced by several factors (Samuel, 2011), the characteristics of the illness consist side effects of medical handlers, duration of treatment, and the complexity of care; personal characteristics consist of age, social support, personality and personal beliefs; cultural norms,

That attitude or motivation of the patient is the most powerful thing itself, as compliance (Sari, 2012). Low motivation to health will greatly influence the behavior of patients in disease control. Confidence is a spiritual dimension to life. Patients with the lowest adherence rates are less committed to the belief and will be so easily discouraged and unable to accept his condition and have an impact on the willingness to control the disease is low. Economic factors such as the cost is too expensive to reach health facilities causing someone did not obey to take medication.

\section{LIMITATION OF THE STUDY}

The limitation of this study was the family support questionnaire, which according to the perception of patients was not from direct family observations.

\section{CONCLUSION}

Most respondents who suffer from cancer in the Tambaksari District Health Center Surabaya receive supportive family support but have a low level of medication adherence for cancer patients. From this study it can be concluded that family support with the level of adherence to the control of cancer patients in undergoing palliative treatment at the Pusaksari District Health Center in Surabaya has a significant relationship. Nursing service institutions are expected to provide health promotion to the families of cancer patients regarding cancer and also the role and support that needs to be given to patients. It is also necessary to hold peer groups specifically for cancer patients so that fellow cancer patients can share experiences to support and strengthen each other in the face of cancer so that the risk of 
complications can be reduced and lead to reductions in mortality and morbidity due to cancer.

\section{REFERENCES}

Balitbang Kemenkes RI. (2013). Riset Kesehatan Dasar. Jakarta: Balitbang Kemenkes RI.

Brannon, L. Feist, J. (2997). Health Psychology: An Introduction To Behavior And Health. California: Brooks/Cole Publishing.

Friedman, MM, Bowden, VR, \& Jones, E. (2010). Family nursing textbook: Research, theory, and practice. Jakarta: EGC.

Grant, M ; Sun, V ; Fujinami, R ; Sidhu, R ; Otis-Green, S ; Juarez, G ; Ferrell, B. (2013). Family caregiver burden/skills preparedness, and quality of life in non-small cell lung cancer.

Green, LW, M. K. (2005). Health program planning: An educational and ecological approach (4th ed.).
Boston: McGraw-Hill.

Kusuma, H. (2011). Hubungan Antara Depresi dan Dukungan Keluarga Dengan Kualitas Hidup Pasien HIV/AIDS yang Menjalani Perawatan di RSUP Cipto Mangunkusumo Jakarta. Universitas Indonesia, 20,21,76-79,111-114,135-139. Retrieved from www.lib.ac.id

Niven, N. (2002). Health Psychology: An Introduction for Nurses and Other Health Professionals. Jakarta: EGC.

Samuel. (2011). Temu Pasien Kanker Payudara: Komitmen, kualitas dan kepatuhan.

Sari, M. (2012). Hubungan dukungan keluarga terhadap motivasi pasien kanker payudara dalam menjalani Kemoterapi di Ruang Cendrawasih I RSUD Arifi n Achmad Provinsi Riau. Jurnal Ners Indonesia. 